OPEN ACCESS

Edited by:

Youji Wang,

Shanghai Ocean University, China

Reviewed by:

Yang Shi Zhang,

Wuhan University of Technology,

China

Tejpal C. S.

Central Institute of Fisheries

Technology (ICAR), India

*Correspondence:

Dapeng LI

Idp@mail.hzau.edu.cn

Specialty section:

This article was submitted to

Aquatic Physiology,

a section of the journal

Frontiers in Physiology

Received: 14 August 2018

Accepted: 13 May 2019

Published: 31 May 2019

Citation:

Zhang X, Wang J, Tang R, He X,

Li L, Takagi Y and Li D (2019)

Improvement of Muscle Quality

of Grass Carp (Ctenopharyngodon idellus) With a Bio-Floating Bed

in Culture Ponds.

Front. Physiol. 10:683.

doi: 10.3389/fphys.2019.00683

\section{Improvement of Muscle Quality of Grass Carp (Ctenopharyngodon idellus) With a Bio-Floating Bed in Culture Ponds}

\author{
Xi Zhang' ${ }^{1}$, Jingwei Wang' ${ }^{1}$, Rong Tang ${ }^{1}$, Xugang He' ${ }^{1} \mathrm{Li} \mathrm{Li}^{1}$, Yasuaki Takagi ${ }^{2}$ and \\ Dapeng $\mathrm{Li}^{1 *}$
}

${ }^{1}$ National Demonstration Center for Experimental Aquaculture Education, Hubei Provincial Engineering Laboratory for Pond Aquaculture, College of Fisheries, Huazhong Agricultural University, Wuhan, China, ${ }^{2}$ Faculty of Fisheries Sciences, Hokkaido University, Sapporo, Japan

Muscle quality and the physiological condition of fish are affected greatly by the culture environment. In aquaculture ponds, a bio-floating bed planted with vegetation is often used to improve water quality. This study investigated the growth and muscle quality of grass carp (Ctenopharyngodon idellus) cultured in ponds equipped with bio-floating beds. Fish were cultured in two replicated pond groups from May to November. Fish in the first group were cultured in experimental ponds equipped with a bio-floating bed planted with Ipomoea aquatica, whereas fish in the other group were reared in control ponds without a bio-floating bed. Compared with control ponds, the experimental ponds had better water quality with significantly lower concentrations of nitrite and ammonia. Grass carp in the experimental group had greater muscle weight gain, a significantly higher content of crude protein, and a significantly lower crude fat level than fish in the control group. The levels of $\mathrm{pH}$, water-holding capacity, and antioxidant capacity of muscle decreased significantly in the control group compared to the experimental group. Texture profile analysis revealed higher values of hardness, springiness, gumminess, and chewiness and lower values of cohesiveness and resilience of white muscle in the experimental group compared to the control group. The filets of fish in the experimental group also received higher grades in the sensory evaluation of springiness, overall acceptability, aroma, and palatability. These results indicate that growth performance and muscle quality of grass carp were improved by the presence of bio-floating beds in the culture ponds.

Keywords: fish, muscle quality, antioxidant capacity, texture profiles analysis, water environment

\section{INTRODUCTION}

Fish growth and muscle quality are affected by external and internal factors, including culture environment, food nutrition, and genetics (Johnston, 2001; Gutierrez et al., 2014; Gisbert et al., 2016; Zhao et al., 2018). Fish quality has been defined as a combination of characteristics such as wholesomeness, freshness, and integrity (Martin, 1998). Freshness, a factor that is crucial to the consumer, is reflected by appearance, taste, and texture of muscle. In addition, nutritional 
composition and water-holding capacity (WHC) have significant impacts on the quality of muscle. These quality parameters are influenced by intrinsic (fish species, size, and sexual maturity) and extrinsic (source of nutrients, season, water salinity, temperature) factors, and nutritional value and sensory characteristics of fish muscle are especially affected by culture conditions (Björnsson and Ólafsdóttir, 2006; Cheng et al., 2014). Consumers generally prefer wild-caught fish because of their superior organoleptic qualities, firmer texture, and better flavor relative to cultured fish (Grigorakis et al., 2003; Periago et al., 2005; Fuentes et al., 2010; Stejskal et al., 2011). Thus, how to produce cultured fish of high quality is a key concern for the aquaculture industry (Valente et al., 2013; Zhao et al., 2018).

Pond culture is the most important aquaculture model in China. However, water contamination, which negatively impacts the water environment and fish quality, has become a serious problem that limits sustainable development of pond culture systems (Björnsson and Ólafsdóttir, 2006; Qin, 2010). To address this problem, bio-floating bed technology has been used in recent years as an ecological remediation method to control water eutrophication. This low-cost, solar-energy-based, and eco-friendly technology has been used for water purification around the world (Wen and Recknagel, 2002; Todd et al., 2003; Garbett, 2005; Nduvamana et al., 2007; Nakai et al., 2008; Stewart et al., 2008). For example a floating-bed planted with Ipomoea aquatica was used in ponds to improve water quality, and significant reductions in nitrite and ammonium concentrations were achieved (Gao and Sun, 2008). Ipomoea aquatica is an aquatic macrophyte that can remove nutrients such as nitrogen and phosphorus and metals such as cadmium and chromium from the water and reduce chemical oxygen demand (COD), biological oxygen demand (BOD), and total suspended solids (TSS) (Hu et al., 2008; Wang et al., 2008; Chen et al., 2010; Chanu and Gupta, 2016).

The grass carp (Ctenopharyngodon idellus) is a popular fish species in freshwater aquaculture (Xie et al., 2018). However, the muscle quality of cultured grass carp has declined in recent years due to the use of artificial feeds and to the contamination of the water environment (Fuentes et al., 2010; Stejskal et al., 2011; Zhao et al., 2018). As water quality is a key factor affecting growth performance of fish (Johnston, 2001; Björnsson and Ólafsdóttir, 2006), addition of a bio-floating bed to culture ponds could purify the eutrophic water ( $\mathrm{Li}$ et al., 2010). Thus, this technology is a promising way to improve the aquatic culture environment and would be likely to have positive effects on fish quality.

Water environment restoration can contribute to better muscle quality of fish in aquaculture systems (Johnston, 2001; Orban et al., 2002; Björnsson and Ólafsdóttir, 2006). Therefore, we hypothesized that the growth performance and muscle quality of cultured grass carp would be enhanced by using a bio-floating bed in aquaculture ponds. The purpose of this study was to investigate the growth and muscle quality of grass carp cultured in ponds equipped with bio-floating beds planted with I. aquatica. Results of this study will add to our understanding of how different aquaculture environments affect the characteristics of grass carp muscle quality and can be applied to improving fish quality by implementing bio-floating bed technology.

\section{MATERIALS AND METHODS}

\section{Experimental Protocol}

This experimental protocol was approved by the Institutional Animal Care and Use Committees of Huazhong Agricultural University, China. Five aquaculture ponds (each $70 \mathrm{~m}$ long $\times 40$ $m$ wide) were used in this study, which took place from May to November at the Field Scientific Observation and Research Station of Pond Culture, Huazhong Agricultural University. Three ponds with bio-floating beds were used as the experimental pond group, and the other two without a bio-floating bed were used as the control group. The bio-floating beds were set up on the water surface of the experimental ponds (Figure 1). Each experimental pond contained four bio-floating beds that together covered $7.5 \%$ of the water surface area. After installation, each bio-floating bed was planted with I. aquatica with $20 \mathrm{~cm}$ distance between and within rows. Grass carp was the major cultured species (size, $60 \mathrm{~g} /$ tail) in the pond. Table 1 lists the fish species and their numbers in the five ponds. The fish density was the same in both the experimental and control ponds. The fish were fed to satiation with identical feeds (Haid Group Co., Ltd., China) containing crude protein $(28.00 \%)$, crude fat $(7.06 \%)$, moisture (8.75\%), crude fiber (15.00\%), and ash (15.63\%).

\section{Water Quality Measurements}

Water samples were collected from each pond every month during the experimental period. All water samples were obtained by mixing samples from upper, middle, and lower water layers. Each 200-mL water sample was filtered (Whatman GF/C glass-fiber $0.45 \mu \mathrm{m}$ pore size) and analyzed for ammonium nitrogen $\left(\mathrm{NH}_{4}{ }^{+}-\mathrm{N}\right)$, nitrite nitrogen $\left(\mathrm{NO}_{2}{ }^{-}-\mathrm{N}\right)$, nitrate nitrogen $\left(\mathrm{NO}_{3}{ }^{-}-\mathrm{N}\right)$, and phosphate $\left(\mathrm{PO}_{4}{ }^{3-}-\mathrm{P}\right)$. Unfiltered subsamples were analyzed for total nitrogen (TN) and total phosphorus (TP). $\mathrm{NH}_{4}{ }^{+}-\mathrm{N}, \mathrm{NO}_{2}^{-}-\mathrm{N}, \mathrm{NO}_{3}{ }^{-}-\mathrm{N}$, and $\mathrm{TP}$ contents were measured using the Nesslerization colorimetric (GB/T7479-1987), diazonium coupled spectrophotometric (GB/T7493-1987), UV spectrophotometric (HJ/T346-2007), and molybdate spectrophotometric (GB/T11893-1989) methods, respectively. $\mathrm{PO}_{4}{ }^{3-}-\mathrm{P}$ was measured according to the method of the Editorial Board of Monitoring and Analytical Methods of Water and Wastewater (2002).

The $\mathrm{PO}_{4}{ }^{3-}-\mathrm{P}$ concentrations in experimental ponds were significantly lower than those of the control ponds from June and November. The concentrations of TP in the experimental ponds were significantly lower than those of the control ponds in July, October, and November (Figure 2). There were no differences in the values of the nitrogen parameters among all ponds from May to July. However, from August to November, the $\mathrm{NH}_{4}{ }^{+}-\mathrm{N}$ values of the experimental ponds were significantly lower than those of the control ponds. The concentrations of either $\mathrm{NO}_{2}{ }^{-}-\mathrm{N}$ or $\mathrm{NO}_{3}{ }^{-}-\mathrm{N}$ were significantly lower in the experimental ponds than in the control ponds in the late experimental period (Figure 3).

\section{Biometric Measurements}

Twenty grass carp from each pond were sampled, and the fish were anesthetized with MS-222 (50 mg/L). Fish were individually 

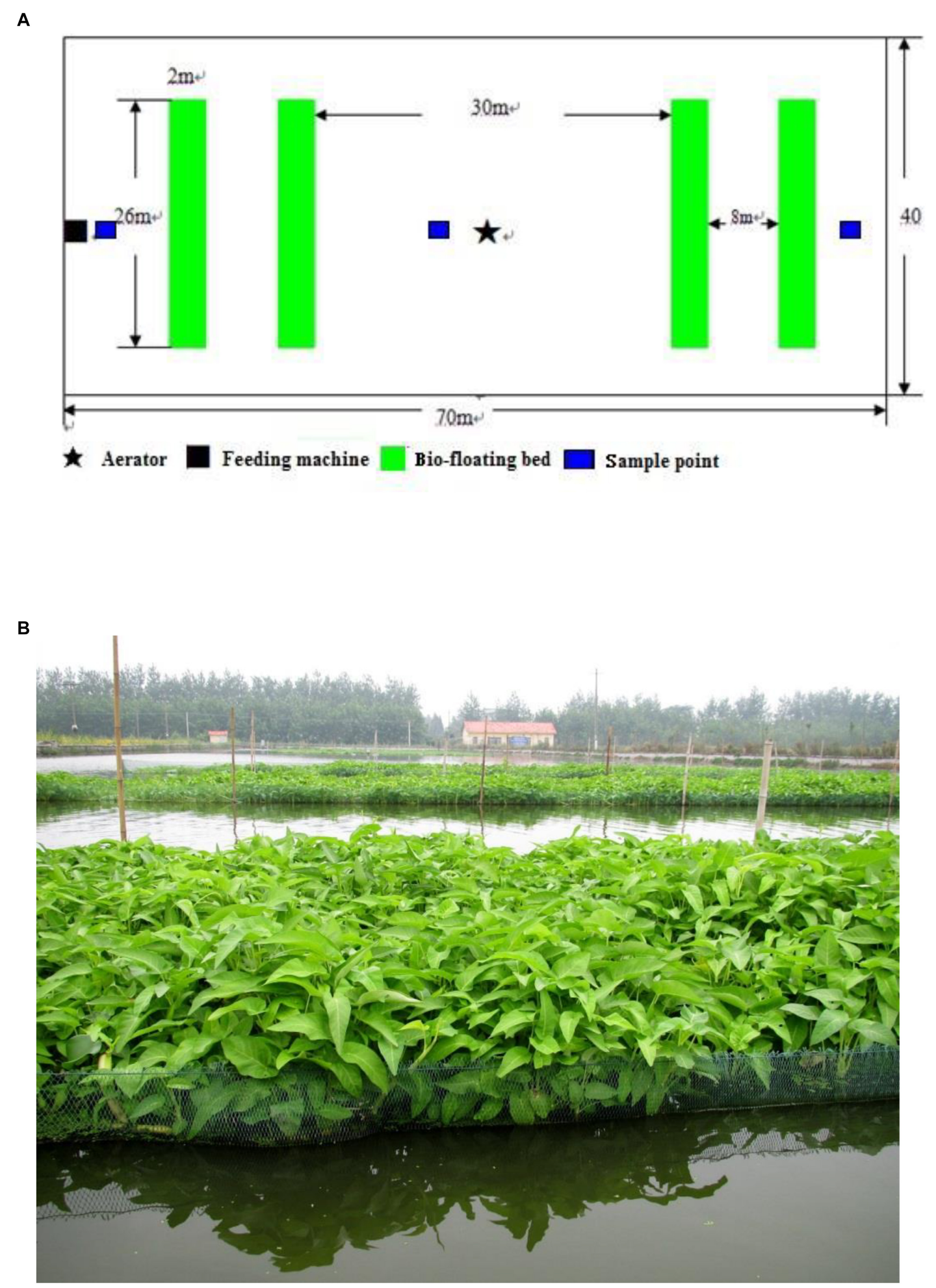

FIGURE 1 | Schematic diagram of equipping the bio-floating bed in the pond (A) and the scenery of bio-floating bed planted with Ipomoea aquatica (B).

weighed to obtain total weight (TW) and measured to obtain standard length $(\mathrm{SL})$, height $(\mathrm{H})$, and width $(\mathrm{W})$. Condition factor $(\mathrm{CF})$ was calculated as $\mathrm{CF}=\left(\mathrm{TW} / \mathrm{SL}^{3}\right) \times 100$. Multiples of weight gain was calculated as final weight/initial weight. Liver and visceral mass were weighed to obtain liver weight (LW) and visceral mass weight (VW), and the liver somatic index and 
TABLE 1 | Fish species, size, and amount cultured in one pond.

\begin{tabular}{lcc}
\hline Species & Size (g) & Amount (kg) \\
\hline Ctenopharyngodon idellus & 60 & 190 \\
Hypophthalmichthys molitrix & 400 & 40 \\
& 1460 & 50 \\
Aristichthys nobilis & 700 & 12.5 \\
& 100 & 8 \\
& 1060 & 40 \\
\hline
\end{tabular}

the visceral mass ratio were calculated as $(\mathrm{LW} / \mathrm{TW}) \times 100$ and $(\mathrm{VW} / \mathrm{TW}) \times 100$, respectively. Total muscle $(\mathrm{MW})$ was weighed, and the flesh content was calculated as $(\mathrm{MW} / \mathrm{TW}) \times 100$.

\section{Chemical Composition of Muscle}

Dorsal white muscles of fish were sampled and kept frozen $\left(-20^{\circ} \mathrm{C}\right)$ for chemical analysis. Chemical composition of muscle was measured according to methods provided by the National Food Safety Standard of P. R. of China. Water content was determined by method GB 5009.3-2010; ash by method GB 5009.3-2010; crude protein by the Kjeldahl method (GB 5009.5-2010), and lipid by the Soxhlet method (GB/T 5009.6-2003).

\section{pH and Water-Holding Capacity (WHC)}

Muscle pH was measured using a Testo 205 pH meter (Testo AG, Lenzkirch, Germany). WHC of the samples was measured by drip loss, stored loss, frozen leakage rate, and cooked rate. In order to eliminate the effects of different parts of the muscle on the WHC, we used $5 \mathrm{~g}$ of muscle taken from the same location of each fish for the analyses. To calculate drip loss, we placed the muscle in a plastic bag hanging for $48 \mathrm{~h}$ at $4^{\circ} \mathrm{C}$ and weighed it again. To calculate the stored loss, the muscle was placed in a tightly sealed plastic bag, stored at $4^{\circ} \mathrm{C}$ for $24 \mathrm{~h}$, and weighed again. To obtain the frozen leakage rate, muscle was kept for $24 \mathrm{~h}$ at $-20^{\circ} \mathrm{C}$, tightly sealed in a plastic bag at $4^{\circ} \mathrm{C}$, and weight at 0,1 , and $2 \mathrm{~h}$. The cooked rate was calculated by weighing the muscle after it was cooked for $15 \mathrm{~min}$.

\section{Antioxidant Assays}

Total antioxidant capacity (T-AOC), activities of superoxide dismutase (SOD), lipid peroxidation (LPO), and protein carbonylation (PC) were measured in blood serum, liver, and muscle. Before sampling, fish were anesthetized with MS222 (100 $\left.\mathrm{mg} \mathrm{L}^{-1}\right)$. The blood samples were drawn using 2-mL syringes and collected in $1.5-\mathrm{mL}$ reaction vials. The serum was obtained by centrifugation at $2,000 \times g$ at $4^{\circ} \mathrm{C}$ for $20 \mathrm{~min}$ and then stored at $-80^{\circ} \mathrm{C}$ until the assay. Liver and muscle samples were homogenized $(1: 9 \mathrm{w} / \mathrm{v})$ in a cold $\left(4^{\circ} \mathrm{C}\right)$ phosphate buffer solution. The homogenate was centrifuged at 3,000 $\times g$ for $15 \mathrm{~min}$ at $4^{\circ} \mathrm{C}$, and then the supernatant was collected for the assay. T-AOC, SOD, LPO, and PC were measured following the manufacturer's instructions for the total antioxidant capacity assay kit (ABTS method), superoxide dismutase kit, malondialdehyde (MDA) assay kit (TBA method), and protein carbonyl assay kit, respectively (Nanjing Jiancheng Biochemical Corporation, Nanjing, China).

\section{Texture Measurements and Sensory Evaluation}

The texture of muscle was evaluated using a TA-XT Plus Micro TPA device (Stable Micro Systems, Godalming, United Kingdom) equipped with a flat-bottomed cylindrical probe P/36R and a load cell of $250 \mathrm{~N}$. The assay was performed following the method described by Ma et al. (2014) with minor modifications. All texture profiles analysis (TPA) measurements were performed using $2 \mathrm{~cm} \times 2 \mathrm{~cm} \times 2 \mathrm{~cm}$ pieces from the dorsal white muscle of each fish. The probe was pressed downward at a constant speed of $1 \mathrm{~mm} / \mathrm{s}$ into the sample until it reached $60 \%$ of the sample height, and the samples were compressed twice for each TPA test. Test conditions were as follows: a pre-test speed of $2 \mathrm{~mm} / \mathrm{s}$, a test speed of $1 \mathrm{~mm} / \mathrm{s}$, and a post-test speed of $5 \mathrm{~mm} / \mathrm{s}$ with the stay time of $5 \mathrm{~s}$. Filet heights and the maximum force ( $\mathrm{g}$ shear force) needed to compress filets to $70 \%$ of their height were measured. The TPA and shear force tests were carried out at room temperature; five fish from each pond, with three parallel samples from each fish, were used. Texture curves were generated, and the maximum force was determined as an average of the three measurements.

Sensory analysis of filets was performed by 17 judges who had been trained to test the samples. Eleven sensory indices (color, gloss, texture, springiness, chewiness, sour smell, residues, juiciness, palatability, aroma, acceptability) were judged on a scale from 1 to 9 , where 1 indicated no intensity and 9 indicated clear intensity (Table 2).

\section{Statistical Analysis}

Results are shown as mean with standard deviation. Statistical analyses were performed using SPSS Base 19.0 statistical software (IBM, Armonk, NY, United States). The differences between the control group and experimental group were evaluated by one-way analysis of variance (ANOVA) followed by Duncan's multiple comparison tests when differences were found using the ANOVA. Statistically significant differences were determined at $P<0.05$ for all analyses.

\section{RESULTS}

\section{Growth Performance}

The biometric measurements of fish in the experimental ponds differed from those in the control ponds (Table 3). The average weight and multiples of weight gain were significantly higher in the experimental group compared with the control group $(P<0.05)$. There were no significant differences in SL, H, and $\mathrm{W}$ between the two groups. Although both CF and visceral mass ratio did not differ significantly between the two groups, the fish had a significantly higher liver somatic index in the control ponds.

\section{Chemical Composition of Muscle}

Table 4 shows the flesh content, chemical composition of muscle, and cooked rate. There was no difference in the 

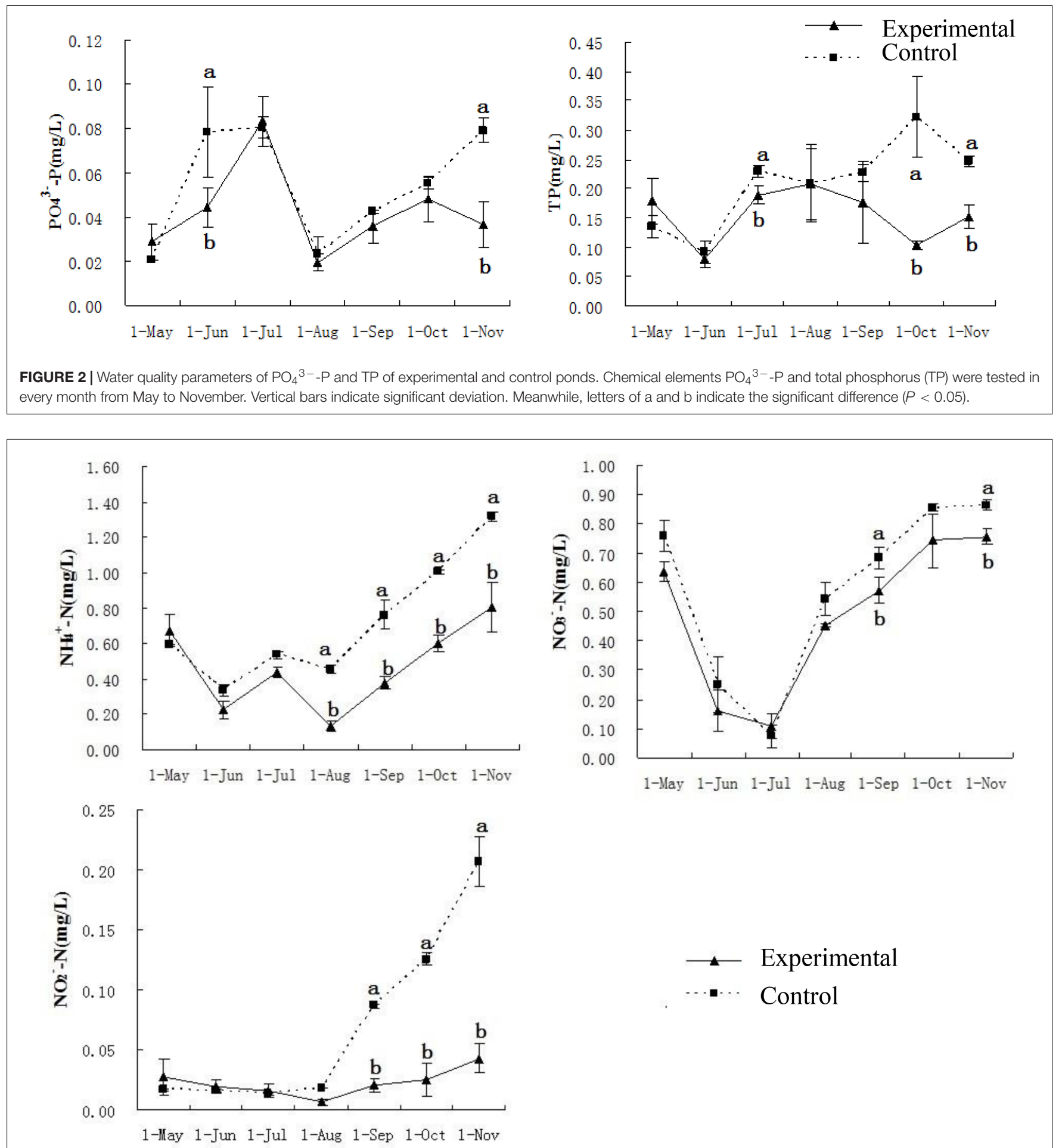

\section{$\leftarrow$ Experimental}

-.... Control

FIGURE 3 | Water quality parameters of nitrogen of experimental and control ponds. Chemical elements of three various forms of nitrogen $\left(\mathrm{NH}_{3} / \mathrm{NH}_{4}{ }^{+}, \mathrm{NO}_{3}{ }^{-}\right.$, $\mathrm{NO}_{2}{ }^{-}$) were tested in every month from May to November. Vertical bars indicate significant deviation. Meanwhile, letters of a and $b$ indicate the significant difference $(P<0.05)$.

content of water, crude ash, and flesh content between the two groups. The fish in the experimental ponds had significantly lower fat content $(P<0.01)$ and higher protein content
$(P<0.05)$ than those in the control ponds. A higher cooked rate $(76.74 \%)$ was observed in the fish from the experimental ponds $(P<0.01)$. 
TABLE 2 | Parameters of sensory evaluation of cooked muscle.

\begin{tabular}{|c|c|c|}
\hline \multirow{2}{*}{$\begin{array}{l}\text { Parameter } \\
\text { White }\end{array}$} & \multicolumn{2}{|c|}{ Score } \\
\hline & 1: Very weak & 9: Intense \\
\hline Gloss & 1: Very weak & 9: Intense \\
\hline Texture & 1: Loosely & 9: Very firming \\
\hline Springiness & 1: Not elastic & 9: Very elastic \\
\hline Juiciness & 1: Dry & 9: Very juicy \\
\hline Palatability & 1: Distasteful & 9: Very palatable \\
\hline Aroma & 1: Not detected & 9: Very fragrant \\
\hline Chewiness & 1: Not chewy & 9: Very chewy \\
\hline Sourish smell & 1: Sourish smell & 9: Not detected \\
\hline Residues & 1: Many residues & 9: Not detected \\
\hline Acceptability & 1: Distasteful & 9: Love \\
\hline
\end{tabular}

TABLE 3 | Growth performance of the grass carp from the experimental and control ponds.

\begin{tabular}{lcc}
\hline & Experimental & Control \\
\hline Weight $(\mathrm{g})$ & $723.06 \pm 77.20^{*}$ & $641.40 \pm 37.40$ \\
Length $(\mathrm{cm})$ & $35.09 \pm 4.66$ & $33.58 \pm 0.47$ \\
Height $(\mathrm{cm})$ & $7.47 \pm 1.18$ & $7.27 \pm 0.05$ \\
Width $(\mathrm{cm})$ & $5.23 \pm 0.81$ & $5.17 \pm 0.05$ \\
Multiples of weight gain & $12.06 \pm 0.62^{*}$ & $10.69 \pm 0.12$ \\
Visceral mass ratio $(\%)$ & $12.21 \pm 0.16$ & $12.24 \pm 0.90$ \\
Liver somatic index $(\%)$ & $2.19 \pm 0.30$ & $2.40 \pm 0.01^{*}$ \\
Condition factor $\left(\mathrm{g} / \mathrm{cm}^{3}\right)$ & $1.72 \pm 0.02$ & $1.70 \pm 0.01$ \\
\hline
\end{tabular}

Vales represent means $\pm S D$, * indicates significant difference $(P<0.05)$ between the experimental and the control groups.

\section{$\mathrm{pH}$ and WHC of Muscle}

The fish in the experimental ponds had a significantly higher $\mathrm{pH}$ level and WHC than the fish in the control ponds (Table 5). Drip loss, stored loss, and initial frozen leakage rate were all significantly lower in fish from the experimental ponds than in fish from the control ponds $(P<0.01)$. As thawing progressed, the difference between the loss of water from muscle from experimental and control pond fish increased sharply, resulting in a significant difference $(P<0.01)$.

\section{Antioxidant Capacity}

The antioxidant capacity in serum, liver, and muscle differed significantly between the two groups (Figure 4). The fish in the experimental ponds had lower SOD activity in muscle and liver compared with fish in the control ponds. Higher T-AOC was detected in the liver of fish in the experimental ponds $(P<0.05)$. The concentrations of MDA and PC were significantly higher in the serum and liver of fish in the control ponds than in the experimental ponds. No significant difference between the two groups in the concentration of either MDA or PC in the muscle of fish was detected.

\section{Texture Analysis and Sensory Evaluation}

Muscle samples from fish from the experimental group had a higher texture profile (Table 6) and higher sensory evaluation (Figure 5) values than those from the control group. Although samples from the experimental group had consistently higher values of hardness, springiness, gumminess, chewiness, cohesiveness, and resilience compared to the control group, the differences were not statistically significant (Table 6). The sensory evaluation values for springiness, acceptability, aroma, and palatability were significantly higher in the experimental group compared to the control group (Figure 5).

\section{DISCUSSION}

In this study, water quality and fish muscle quality were improved by the presence of bio-floating beds in the experimental ponds compared with the control ponds which lacked the beds. Aquatic plants have been widely applied in ecological engineering to improve the quality of surface water and wastewater (Garbett, 2005; Nduvamana et al., 2007). The observed lower concentrations of nitrite, ammonia, and phosphate in the experimental ponds illustrates that water quality was improved significantly by the bio-floating beds in the intensive culture

TABLE 4 | Composition and cooked rate of muscle in grass carps from experimental and control ponds.

\begin{tabular}{|c|c|c|c|c|c|c|}
\hline & Water content (\%) & Fat (\%) & Crude protein (\%) & Crude ash (\%) & Flesh content (\%) & Cooked rate (\%) \\
\hline Experimental & $79.66 \pm 0.30$ & $1.13 \pm 0.06$ & $17.75 \pm 0.13^{*}$ & $1.09 \pm 0.01$ & $63.91 \pm 0.23$ & $76.74 \pm 1.59^{* *}$ \\
\hline Control & $80.12 \pm 0.09$ & $1.41 \pm 0.06^{* *}$ & $17.33 \pm 0.07$ & $1.10 \pm 0.01$ & $63.64 \pm 0.09$ & $74.33 \pm 0.17$ \\
\hline
\end{tabular}

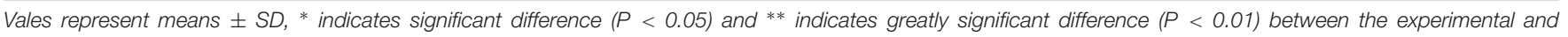
the control groups.

TABLE $\mathbf{5}$ | pH and water holding capacity of muscle in grass carps from experimental and control ponds.

\begin{tabular}{|c|c|c|c|c|c|c|}
\hline & $\mathrm{pH}$ & Drip loss (\%) & Stored loss (\%) & $\begin{array}{l}\text { Frozen leakage } \\
\text { rate } 0 \mathrm{~h}(\%)\end{array}$ & $\begin{array}{l}\text { Frozen leakage } \\
\text { rate } 1 \mathrm{~h}(\%)\end{array}$ & $\begin{array}{l}\text { Frozen leakage } \\
\text { rate } 2 \text { h (\%) }\end{array}$ \\
\hline Experimental & $6.06 \pm 0.04^{*}$ & $1.77 \pm 0.13$ & $1.07 \pm 0.05$ & $1.06 \pm 0.01$ & $1.47 \pm 0.06$ & $2.10 \pm 0.06$ \\
\hline Control & $5.92 \pm 0.04$ & $2.11 \pm 0.08^{* *}$ & $1.33 \pm 0.14^{* *}$ & $1.26 \pm 0.13^{*}$ & $1.94 \pm 0.01^{* *}$ & $3.04 \pm 0.10^{* *}$ \\
\hline
\end{tabular}

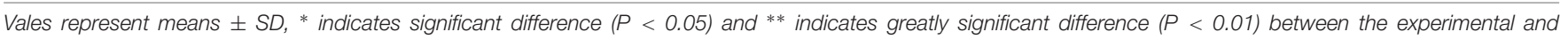
the control groups. 


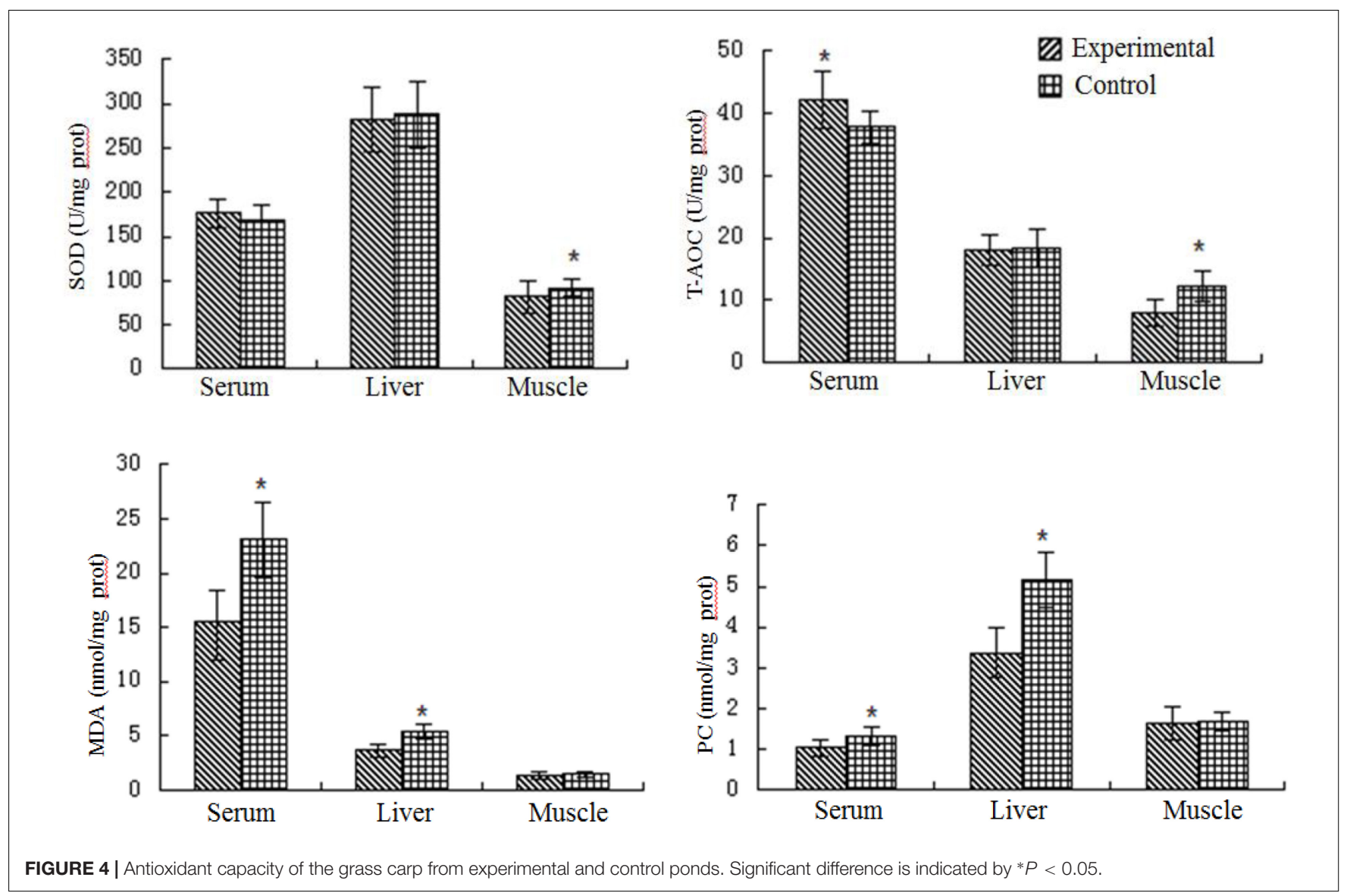

TABLE 6 | Texture profile analysis of muscle in grass carps from experimental and control ponds.

\begin{tabular}{|c|c|c|c|c|c|c|}
\hline & Hardness & Springiness & Cohesiveness & Gumminess & Chewiness & Resilience \\
\hline Experimental & $5269.84 \pm 1047.52$ & $0.63 \pm 0.06$ & $0.28 \pm 0.02$ & $1473.83 \pm 325.55$ & $934.53 \pm 242.50$ & $0.18 \pm 0.03$ \\
\hline Control & $4767.08 \pm 596.97$ & $0.61 \pm 0.05$ & $0.29 \pm 0.03$ & $1358.57 \pm 193.55$ & $832.57 \pm 152.99$ & $0.20 \pm 0.03$ \\
\hline
\end{tabular}

Vales represent means $\pm S D$.

ponds where grass carp were reared in this study. Similar results have been reported in studies of lakes and eutrophic waters ( $\mathrm{Hu}$ et al., 2008; Li et al., 2010). Aquatic plants assimilate nutrients and create favorable conditions for microbial decomposition of organic matter (Wang et al., 2009). Increases in the nitrogen contents in ponds were probably caused by the accumulation of residual feeds and feces in the sediments, resulting in oxygen consumption. Person-Le et al. (1997) also reported a trend of increasing total nitrogen concentration in an intensive culture pond in the late spring and thereafter. Lower $\mathrm{PO}_{4}{ }^{3-}-\mathrm{P}$ and TP concentrations observed in the experimental ponds compared to the control ponds suggested that bio-floating beds could reduce not only nitrogen levels but also phosphorus levels in ponds, supporting the results of other studies (Wen and Recknagel, 2002; Stewart et al., 2008).

Environmental and fish nutritional status are the most important factors that affect fish growth and muscle quality (Johnston, 2001; Larsson et al., 2014). In this study, grass carp cultured in the experimental ponds showed better growth performance in terms of body shape and weight gain than those from control ponds when supplied with the same amounts of nutrients. Water quality is crucial to fish growth (Orban et al., 2002; Björnsson and Ólafsdóttir, 2006), as poor water quality can cause acute or chronic stress and reduce the ability of fish to control homeostasis (Foss et al., 2003; North et al., 2006; Refaey et al., 2017). Thus, the better growth performance of fish in the experimental ponds was attributed primarily to the improved water quality.

The crude protein and fat concentrations of muscle differed between fish from the experimental and control ponds. These differences were probably due to the better water quality in the experimental ponds. Fuentes et al. (2010) reported that wild sea bass (Dicentrarchus labrax) had significantly higher protein concentrations compared to farmed fish. Different protein concentration of fish might be caused by different rearing conditions (Haard, 1992). Fish in the experimental ponds also had lower crude fat content than the fish in the control ponds. In general, crude fat content primarily depends on the feed, fish 


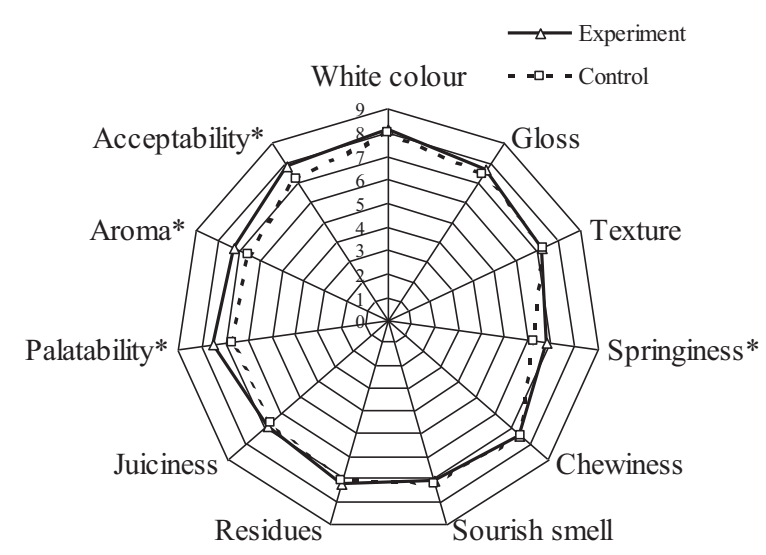

FIGURE 5 | Radar diagram of the average values of sensory properties for the grass carp from experimental and control ponds. Significant difference is indicated by $* P<0.05$

species, and rearing conditions (Love, 1992; Alasalvar et al., 2002; Orban et al., 2002). Lower fat levels in wild fish compared to farmed fish have been observed in some fish species (Alasalvar et al., 2002; Grigorakis et al., 2003; Johnston et al., 2007).

Muscle $\mathrm{pH}$ and WHC are important parameters for evaluating muscle quality. Glycolytic potential, fatty acid composition and concentrations, and some biological reactions affect muscle pH (Fernandez et al., 1992), while pH subsequently strongly influences the WHC. A rapid muscle $\mathrm{pH}$ decline causes soft texture and poor WHC of the muscle (Ang and Haard, 1985; Anne et al., 2016). On the other hand, high muscle WHC can reduce protein breakdown (Bee et al., 2007). The higher WHC and hardness observed in the experimental fish could be related to higher $\mathrm{pH}$ in the muscle, suggesting better muscle quality of grass carp cultured in the ponds with bio-floating beds.

The antioxidant defense system is a highly conserved biochemical mechanism that protects organisms from harmful effects of reactive oxygen species (Birben et al., 2012; Niu et al., 2018). T-AOC is a comprehensive assessment index of antioxidant capacity. The higher T-AOC of grass carp in the experimental ponds indicates that they had greater antioxidant capacity than fish in the control ponds. SOD is an important antioxidant defense in nearly all living cells, as it protects organisms against free radical damage, being the first line of defense in controlling the damaging accumulation of oxygen free radicals (Ramesh et al., 2018). Fish in the control ponds had higher SOD activity than fish in the experimental ponds. This may have been due to greater stress due to the higher nitrite content in the control ponds, which may have activated the antioxidant defense system in the fish to protect themselves (Wang et al., 2004). PC often is used as an indicator of oxidative damage to proteins, and MDA is a product of LPO (Suzuki et al., 2010; Klein et al., 2017). The concentrations of PC and MDA in serum and liver of fish in the experimental ponds were significantly lower than those in the control ponds, which indicates less oxidative damage and LPO in those fish, supporting the idea that the fish cultured in the cleaner water achieved using the bio-floating beds. In addition, liver condition was well from the liver section observation. These results show that fish cultured in a better culture environment had a more effective antioxidative defense system.

Muscle texture is a crucial factor for customer acceptance of and satisfaction with the fish products (Casas et al., 2006; Fuentes et al., 2010). Andersen et al. (1999) reported that higher fat concentration in filets results in less resistance against compression, which indicates a softer texture of fish, and Love (1992) found that lower $\mathrm{pH}$ of muscle results in lower hardness in terms of muscle texture. Thus, the greater hardness of muscle in fish from the experimental group may be related to their lower fat content and higher $\mathrm{pH}$. Water content and distribution are additional factors that have a profound influence on muscle texture, such as hardness and juiciness, and a higher WHC may be associated with harder muscle (Offer et al., 1989; Pearce et al., 2011). In this study, muscle from fish in the experimental ponds had a higher WHC and hardness than did muscle from fish in the control ponds. Previous studies demonstrated that muscle from wild-caught fish had higher hardness and springiness, as they inhabited a better water environment compared to cultured fish (Fuentes et al., 2010; Cheng et al., 2014). In this study, the improved water quality in ponds containing bio-floating beds probably affected fish growth, muscle chemical composition, and result in the differences in texture as well. The correlation between water quality and muscle textural quality is speculated that poor water quality will cause chronic stress and reduce fish ability to control homeostasis (North et al., 2006; Refaey et al., 2017), and then may cause the negative effects on muscle growth, such as the size and number of muscle fiber which is reported to determine muscle texture (Taylor et al., 2006; Damez and Clerjon, 2008). In order to confirm this assumption, related experiments need to be done in the future.

In recent years, sensory evaluation with different scores indicating the freshness parameter has been implemented in several European countries (Cheng et al., 2014). In this study, the difference in quality of fish within ponds was generally lower than those among ponds. Fish from the experimental ponds had better scores for springiness, overall acceptability, aroma, and palatability compared to fish from the control ponds. Muscle $\mathrm{pH}$ is a vital factor that affects fish muscle appearance and sensory evaluation, with higher $\mathrm{pH}$ generally resulting in better scores (Love, 1992; Bee et al., 2007; Luciano et al., 2009). Thus, the better sensory properties of fish from the experimental ponds likely was probably related to their higher muscle $\mathrm{pH}$ which, in turn, was brought about by the reduced level of stress experienced by fish in the cleaner water of the experimental ponds.

\section{CONCLUSION}

This study demonstrated that the presence of bio-floating beds in ponds effectively improved water quality by significantly reducing the concentrations of both nitrite and ammonia in 
the pond water. The improved culture environment enhanced the growth performance, muscle quality, and antioxidative capacity of the grass carp. Compared with the control ponds, grass carp cultured in the experimental ponds showed better growth performance and had higher crude protein and lower fat concentration in their filets due to the better water quality. In addition, muscle from fish from the experimental ponds had higher WHC, higher antioxidant capacity, and better texture properties such as hardness and chewiness than fish from the control ponds. Fish from the experimental ponds also had better sensory evaluation scores for springiness, acceptability, aroma, and palatability. These results indicate that the use of bio-floating beds in culture ponds improves water quality, fish growth, and muscle quality.

\section{REFERENCES}

Alasalvar, C., Taylor, K. D. A., Zubcov, E., Shahidi, F., and Alexis, M. (2002). Differentiation of cultured and wild sea bass (Dicentrarchus labrax): total lipid content fatty acid and trace mineral composition. Food Chem. 79, 145-150. doi: 10.1016/S0308-8146(02)00122-X

Andersen, U. B., Thomassen, M. S., and Røra, A. M. B. (1999). Texture properties of farmed rainbow trout (Oncorhynchus mykiss): effects of diet, muscle fat content and time of storage on ice. J. Sci. Food Agric. 74, 347-353. doi: 10.1002/(sici) 1097-0010(199707)74:3<347::aid-jsfa802>3.0.co;2-f

Ang, J., and Haard, N. F. (1985). Chemical composition and postmortem changes in soft textured muscle from intensely feeding Atlantic cod (Gadius morhua L). J. Food Biochem. 9, 49-64. doi: 10.1111/j.1745-4514.1985.tb00338.x

Anne, L., Bénédicte, L., Isabelle, L., Thierry, A., Muriel, B., Louis, L., et al. (2016). How muscle structure and composition influence meat and flesh quality. Sci. World J. 2016, 1-14. doi: 10.1155/2016/3182746

Bee, G., Anderson, A. L., Lonergan, S. M., and Huff-Lonergan, E. (2007). Rate and extent of $\mathrm{pH}$ decline affect proteolysis of cytoskeletal proteins and waterholding capacity in pork. Meat Sci. 12, 359-365. doi: 10.1016/j.meatsci.2006. 12.004

Birben, E., Sahiner, U. M., Sackesen, C., Erzurum, S., and Kalayci, O. (2012). Oxidative stress and antioxidant defense. World Allergy Organ. J. 5:9. doi: 10.1097/WOX.0b013e3182439613

Björnsson, B., and Ólafsdóttir, S. R. (2006). Effects of water quality and stocking density on growth performance of juvenile cod (Gadus morhua L.). ICES J. Mar. Sci. 63, 326-334. doi: 10.1016/j.icesjms.2005.10.010

Casas, C., Martinez, O., Guillen, M., Pin, C., and Salmeron, J. (2006). Textural properties of raw Atlantic salmon (Salmo salar) at three points along the fillet, determined by different methods. Food Control. 17, 511-515. doi: 10.1016/j. foodcont.2005.02.013

Chanu, L. B., and Gupta, A. (2016). Phytoremediation of lead using Ipomoea aquatica Forsk. in hydroponic solution. Chemosphere 156, 407-411. doi: 10. 1016/j.chemosphere.2016.05.001

Chen, J. C., Wang, K. S., Chen, H., Lu, C. Y., Huang, L. C., Li, H. C., et al. (2010). Phytoremediation of Cr(III) by Ipomonea aquatica (water spinach) from water in the presence of EDTA and chloride: effects of $\mathrm{Cr}$ speciation. Bioresour. Technol. 101, 3033-3039. doi: 10.1016/j.biortech.2009.12.041

Cheng, J. H., Sun, D. W., Han, Z., and Zeng, X. A. (2014). Texture and structure measurements and analyses for evaluation of fish and fillet freshness quality: a review. Compr. Rev. Food Sci. Food Saf. 13, 52-61. doi: 10.1111/1541-4337. 12043

Damez, J. L., and Clerjon, S. (2008). Meat quality assessment using biophysical methods related to meat structure. Meat Sci. 80, 132-149. doi: 10.1016/j.meatsci. 2008.05.039

Fernandez, X., Magard, M., and Tornberg, E. (1992). Glycolytic potential in porcine longissimus muscle before and after transport: an in vivo study. J. Muscle Foods 3, 83-89. doi: 10.1111/j.1745-4573.1992.tb00673.x

\section{AUTHOR CONTRIBUTIONS}

JW, DL, and $\mathrm{XZ}$ were responsible for the design of the experiments. XZ and JW were responsible for the experiments and data analysis. XZ and DL wrote the manuscript. RT, XH, LL, and YT provides some suggestions and gave the final approval.

\section{FUNDING}

This work was supported by the Earmarked Fund for China Agriculture Research System (CARS-45), Fundamental Research Funds for the Central Universities (2662016QD047 and 2662015PY119), and the National Natural Science Foundation of China (31502140).

Foss, A., Rones, B. A., and Oiestad, V. (2003). Graded environmental hypercapnia in juvenile spotted wolffish (Anarhichas minor Olafsen): effects on growth, food conversion efficiency and nephrocalcinosis. Aquaculture 220, 607-617. doi: 10.1016/S0044-8486(02)00613-0

Fuentes, A., Fernández-Segovia, I., Serra, J. A., and Barat, J. M. (2010). Comparison of wild and cultured sea bass (Dicentrarchus labrax) quality. Food Chem. 119, 1514-1518. doi: 10.1016/j.foodchem.2009.09.036

Gao, Y., and Sun, C. (2008). "Purification of stream flowing into Dian Lake by ecological floating-bed system," in Proceedings of 2008 2nd International Conference on Bioinformatics and Biomedical Engineering (ICBBE), (Shanghai).

Garbett, P. (2005). An investigation into the application of floating reed bed and barley straw techniques for the remediation of eutrophic waters. Water Environ. J. 19, 174-180. doi: 10.1111/j.1747-6593.2005.tb01584.x

Gisbert, E., Mozanzadeh, M. T., Kotzamanis, Y., and Estévez, A. (2016). Weaning wild flathead grey mullet (Mugil cephalus) fry with diets with different levels of fish meal substitution. Aquaculture 462, 92-100. doi: 10.1016/j.aquaculture. 2016.04.035

Grigorakis, K., Taylor, K. D. A., and Alexis, M. N. (2003). Organoleptic and volatile aroma compounds comparison of wild and cultured gilthead sea bream (Sparus aurata): sensory differences and possible chemical basis. Aquaculture 225, 109-119. doi: 10.1016/S0044-8486(03)00283-7

Gutierrez, P. T., Almeida, F. L., Carani, F. R., Vechetti, I. J., Padovanic, C. R., and Salomão, R. A. S. (2014). Rearing temperature induces changes in muscle growth and gene expression in juvenile pacu (Piaractus mesopotamicus). Comp. Biochem. Physiol. B 169, 31-37. doi: 10.1016/j.cbpb.2013.12.004

Haard, N. F. (1992). Control of chemical composition and food quality attributes of cultured fish. Food Res. Int. 25, 289-307. doi: 10.1016/0963-9969(92)90126- P

Hu, M. H., Ao, Y. S., Yang, X. E., and Li, T. Q. (2008). Treating eutrophic water for nutrient reduction using an aquatic macrophyte (Ipomoea aquatica Forsskal) in a deep flow technique system. Agric. Water Manage. 95, 607-615. doi: 10.1016/j.agwat.2008.01.001

Johnston, I. A. (2001). Genetic and environmental determinants of muscle growth patterns. Fish Physiol. Biochem. 18, 141-186. doi: 10.1016/S1546-5098(01) 18007-6

Johnston, I. A., Bickerdikeb, R., Li, X. J., Dingwall, A., Nickell, D., Alderson, R., et al. (2007). Fast growth was not associated with an increased incidence of soft flesh and gaping in two strains of Atlantic salmon (Salmo salar) grown under different environmental conditions. Aquaculture 265, 148-155. doi: 10.1016/j. aquaculture.2007.01.045

Klein, R. D., Rosa, C. E., Colares, E. P., Robaldo, R. B., Martinez, P. E., and Bianchini, A. (2017). Antioxidant defense system and oxidative status in Antarctic fishes: the sluggish rockcod Notothenia coriiceps versus the active marbled notothen Notothenia rossii. J. Therm. Biol. 68(Pt A), 119-127. doi: 10.1016/j.jtherbio.2017.02.013

Larsson, T., Koppang, E. O., Espe, M., Terjesen, B. F., Krasnov, A., Moreno, H. M., et al. (2014). Fillet quality and health of Atlantic salmon (Salmo salar L.) fed 
a diet supplemented with glutamate. Aquaculture 42, 288-295. doi: 10.1016/j. aquaculture.2014.01.034

Li, X., Song, H., Li, W., Lu, X., and Nishimura, O. (2010). An integrated ecological floating-bed employing plant, freshwater clam and biofilm carrier for purification of eutrophic water. Ecol. Eng. 36, 382-390. doi: 10.1016/j.ecoleng. 2009.11.004

Love, R. M. (1992). "Biochemical dynamics and the quality of fresh and frozen fish,” in Fish Processing Technology, ed. G. M. Hall (New York, NY: Balckie Academic), $1-30$.

Luciano, G., Monahan, F. J., Vasta, V., Biondi, L., Lanza, M., and Priolo, A. (2009). Dietary tannins improve lamb meat colour stability. Meat Sci. 81, 120-125. doi: 10.1016/j.meatsci.2008.07.006

Ma, L. Q., Qi, C. L., Cao, J. J., and Li, D. P. (2014). Comparative study on muscle texture profile and nutritional value of channel catfish (Ictalurus punctatus) reared in ponds and reservoir cages. J. Fish. China 38, 532-537. doi: 10.3724/ SP.J.1231.2014.48963

Martin, R. (1998). Contaminants in relation to the quality of seafoods. Food Technol. 42:104.

Monitoring and Analytical Methods of Water and Wastewater (2002). Editorial Committee of 'Monitoring and Analytical Methods of Water and Wastewater', 4th Edn. Beijing: The State Environmental Protection Administration of China (SEPA).

Nakai, S., Zou, G., Song, X., Pan, Q., Zhou, S., and Hosomi, M. (2008). Release of anti-cyanobacteria allelochemicals from aquatic and terrestrial plants applicable for artificial floating islands. J. Water Environ. Technol. 6, 55-63. doi: 10.2965/ jwet.2008.55

Nduvamana, A., Yang, X.-L., and Wang, L. R. (2007). Evaluation of a cost effective technique for treating aquaculture water discharge using Lolium perenne Lam as a biofilter. J. Environ. Sci. 19, 1079-1085. doi: 10.1016/S1001-0742(07)60176-4

Niu, Y., Cao, W., Zhao, Y., Zhai, H., Zhao, Y., Tang, X., et al. (2018). The levels of oxidative stress and antioxidant capacity in hibernating Nanorana parkeri. Comp. Biochem. Phys. A 219-220, 19-27. doi: 10.1016/j.cbpa.2018. 02.003

North, B. P., Turnbull, J. F., Ellis, T., Porter, M. J., Miguad, H., Bron, J., et al. (2006). The impact of stocking density on the welfare of rainbow trout (Oncorhynchus mykiss). Aquaculture 5, 466-479. doi: 10.1016/j.aquaculture.2006.01.004

Offer, G., Knight, P., Jeacocke, R., Almond, R., Cousins, T., Elsey, J., et al. (1989). The structural basis of the water-holding, appearance and toughness of meat and meat products. Food Microstruct. 8, 151-170.

Orban, E., Di Lena, G., Nevigato, T., Casini, I., Santaroni, G., Marzetti, A., et al. (2002). Quality characteristics of sea bass intensively reared and from lagoon as affected by growth conditions and the aquatic environment. J. Food Sci. 67, 542-546. doi: 10.1111/j.1365-2621.2002.tb10635.x

Pearce, K. L., Rosenvold, K., Andersen, H. J., and Hopkins, D. L. (2011). Water distribution and mobility in meat during the conversion of muscle to meat and ageing and the impacts on fresh meat quality attributes-a review. Meat Sci. 89, 111-124. doi: 10.1016/j.meatsci.2011.04.007

Periago, M. J., Ayala, M. D., Lopez, A. O., Abdel, I., Martínez, C., García, A. A., et al. (2005). Muscle cellularity and flesh quality of wild and farmed sea bass, Dicentrarchus labrax L. Aquaculture 249, 175-188. doi: 10.1016/j.aquaculture. 2005.02.047

Person-Le, R. J., Galland, R., Le Roux, A., and Chartois, H. (1997). Chronic ammonia toxicity in juvenile turbot (Scophthalmus maximus). Aquaculture 154, 155-171. doi: 10.1016/S0044-8486(97)00052-5

Qin, Z. Q. (2010). Effects of feeding different raw materials on growth and flesh quality of grass carp Ctenopharyngodon idellus. J. Fujian Fish. 2010, 81-85. doi: 10.3969/j.issn.1006-5601.2010.01.021

Ramesh, M., Thilagavathi, T., Rathika, R., and Poopal, R. K. (2018). Antioxidant status, biochemical, and hematological responses in a cultivable fish Cirrhinus mrigala exposed to an aquaculture antibiotic Sulfamethazine. Aquaculture 491, 10-19. doi: 10.1016/j.aquaculture.2018.02.046

Refaey, M., Tian, X., Tang, R., and Li, D. (2017). Changes in physiological responses, muscular composition and flesh quality of channel catfish Ictalurus punctatus suffering from transport stress. Aquaculture 478, 9-15. doi: 10.1016/ j.aquaculture.2017.01.026

Stejskal, V., Vejsada, P., Cepak, M., Špicka, J., Vacha, F., Kouril, J., et al. (2011). Sensory and textural attributes and fatty acid profiles of fillets of extensively and intensively farmed Eurasian perch (Perca fluviatilis L.). Food Chem. 129, 1054-1059. doi: 10.1016/j.foodchem.2011.05.073

Stewart, F. M., Mulholland, T., Cunningham, A. B., Kania, B. G., and Osterlund, M. T. (2008). Floating islands as an alternative to constructed wetlands for treatment of excess nutrients from agricultural and municipal wastes-results of laboratory-scale tests. Land Contam. Reclam. 16, 25-33. doi: 10.2462/096705 13.874

Suzuki, Y. J., Carini, M., and Butterfield, D. A. (2010). Protein carbonylation. Antioxid. Redox Signal. 12, 323-325. doi: 10.1089/ars.2009.2887

Taylor, R. G., Fjaera, S. O., and Skjervold, P. O. (2006). Salmon fillet texture is determined by myofiber-myofiber and myofiber - myocommata attachment. J. Food Sci. 67, 2067-2071. doi: 10.1111/j.1365-2621.2002.tb09502.x

Todd, J., Brown, E. J. G., and Wells, E. (2003). Ecological design applied. Ecol. Eng. 20, 421-440. doi: 10.1016/j.ecoleng.2003.08.004

Valente, L. M. P., Moutou, K. A., Conceição, L. E. C., Engrola, S., Fernandes, J. M. O., and Johnston, I. A. (2013). What determines growth potential and juvenile quality of farmed fish species? Rev. Aquacult. 5, 168-193. doi: 10.1111/ raq. 12020

Wang, G. X., Zhang, L. M., Chua, H., Li, X. D., Xia, M. F., and Pu, P. M. (2009). A mosaic community of macrophytes for the ecological remediation of eutrophic shallow lakes. Ecol. Eng. 35, 582-590. doi: 10.1016/j.ecoleng.2008.06.006

Wang, K. S., Huang, L. C., Lee, H. S., Chen, P. Y., and Chang, S. H. (2008). Phytoextraction of cadmium by Ipomoea aquatica (water spinach) in hydroponic solution: effects of cadmium speciation. Chemosphere 72, 666-672. doi: 10.1016/j.chemosphere.2008.03.034

Wang, W. N., Wang, A. L., Zhang, Y. J., Li, Z. H., Wang, J. X., and Sun, R. Y. (2004). Effects of nitrite on lethal and immune response of Macrobrachium nipponense. Aquaculture 232, 679-686. doi: 10.1016/j.aquaculture.2003. 08.018

Wen, L., and Recknagel, F. (2002). In situ removal of dissolved phosphorus in irrigation drainage water by planted floats: preliminary results from growth chamber experiment. Agric. Ecosyst. Environ. 90, 9-15. doi: 10.1016/S01678809(01)00292-4

Xie, C., Li, J., Li, D., Shen, Y., Gao, Y., and Zhang, Z. (2018). Grass Carp: The Fish that Feeds Half of China. Hoboken, NJ: Wiley.

Zhao, H., Xia, J., Zhang, X., He, X., Li, L., Tang, R., et al. (2018). Diet affects muscle quality and growth traits of grass carp (Ctenopharyngodon idellus): a comparison between grass and artificial feed. Front. Physiol. 9:283. doi: 10.3389/ fphys.2018.00283

Conflict of Interest Statement: The authors declare that the research was conducted in the absence of any commercial or financial relationships that could be construed as a potential conflict of interest.

Copyright (c) 2019 Zhang, Wang, Tang, He, Li, Takagi and Li. This is an openaccess article distributed under the terms of the Creative Commons Attribution License (CC BY). The use, distribution or reproduction in other forums is permitted, provided the original author(s) and the copyright owner(s) are credited and that the original publication in this journal is cited, in accordance with accepted academic practice. No use, distribution or reproduction is permitted which does not comply with these terms. 